Walter Methlagl*

Innsbruck

\title{
Konflikt aspektów. Ferdinanda Ebnera „myślenie w odniesieniach"
}

Rzadko spotyka się tak ostry kontrast między unikaniem udziału w życiu publicznym, między odosobnieniem przestrzennym, a prawdopodobnie i psychicznym, a z drugiej strony niepohamowanym naciskiem na zdobywanie na bieżąco informacji z różnych dziedzin nauki, chęcią trzymania ręki na pulsie wydarzeń, jak w tych zapiskach Ferdinanda Ebnera, które towarzyszą powstawaniu jego Fragmentów pneumatologicznych ${ }^{1}$. Fakt, że w miejscowości położonej tak bardzo na uboczu, jak Gablitz na początku XX wieku, ktoś tak wytrwale i niezmiennie uzyskiwał dostęp do książek, do wydawanych w tamtych czasach mediów, brał udział w wydarzeniach naukowych i kulturalnych, jak czynił to przez całe lata Ferdinand Ebner, jest wręcz trudny do zrozumienia. Dość często Ebnerowi zarzucano monomanię, myślenie z ,klapkami na oczach”, fiksację intelektualną - autorom tych zarzutów wydawało się, że w ten sposób wyjaśniają jego wytrwałą refleksję nad podejściem, które legło u podstaw Fragmentów.

* Prof. Walter Methlagl (obecnie na emeryturze) jest germanistą i filozofem, był założycielem i długoletnim dyrektorem Instytutu Badawczego Brenner Archiv przy Leopold-Franzens-Universität w Innsbrucku, a także wieloletnim Prezydentem Międzynarodowego Towarzystwa Ferdinanda Ebnera. Adres: Internationale Ferdinand Ebner Gesellschaft, Gries 7, A-6091 Götzens, Austria; e-mail: walter_methlagl@yahoo.at

${ }^{1}$ Przede wszystkim chodzi o Tagebuch 1916 oraz Korespondencję z czasów przed i podczas I wojny światowej. 
Jest coś „na rzeczy” w takich wyjaśnieniach: podejście to polega ostatecznie na ,jednym jedynym przemyśleniu z perspektywy języka"2, na odkryciu, że nie ma żadnego Ja absolutnego, lecz tylko istniejące „relatywnie”, w relacji do Ty. Łatwo jednak przeoczyć, z jaką samokrytyką i samokontrolą, z jak głębokim zastanowieniem i rosnącym przekonaniem o jej wyższości Ebner przez całe lata tę otwierającą się stopniowo perspektywę obserwuje, a także w wielu kierunkach wypróbowuje, uwyraźnia i w końcu potwierdza.

To, co Ebner wypowiedział i wypowiada we Fragmentach pneumatologicznych, ale także w pismach poprzedzających je czy następujących bezpośrednio po nich, zorientowane jest na to podejście. Wypracowana przez Ebnera „perspektywę językową” można, wychodząc od jej zakorzenienia w tradycji i praktyce, określić w szerszym sensie jako „grę językową”, jak opisał to dużo później Ludwig Wittgenstein w swoich Dociekaniach filozoficznych. Pisze on: „Słowo «gra językowa» ma tu podkreślać, że mówienie jest częścią pewnej czynności albo formy życia”’3. Szczególnie ciekawe i wciąż nowatorskie w głównym dziele Ebnera jest to, że ta orientacja, że tak powiem: sprowadzenie rozważań do najkrótszej formuły, wyniosła (i czyni to nadal) na światło dzienne cały szereg aspektów i perspektyw, które tworzą nie mniej niż „formę życia” danej epoki.

Jako przykłady z czasu powstawania Fragmentów wymieńmy tu najpierw kilka postaci współczesnych Ebnerowi, do których odnosił się on w charakterystyczny dla siebie sposób, częściowo w osobistych kontaktach: pisarz Karl Kraus, bez którego „modelu języka” nie do pomyślenia byłby jego własny projekt perspektywy języka; architekt Adolf Loos, który między innymi starał się pozyskać Ebnera jako nauczyciela do szkoły Eugenii Schwarzwald ${ }^{5}$; malarz Johannes Itten, którego geometryczne kompozycje doczekały się ze strony Ebnera pierwszej analizy ${ }^{6}$ i który także chciał zachęcić Ebnera do podjęcia pracy nauczycielskiej w Bauhaus w Weimarze;

${ }^{2}$ Ludwig Ficker, „Geleitwort”, w: Ferdinand Ebner, Schriften, t. 1: Fragmente Aufsätze Aphorismen. Zu einer Pneumatologie des Wortes (München: Kösel, 1963), 11.

${ }^{3}$ Ludwig Wittgenstein, Schriften, t. 1 (Frankfurt a. M.: Suhrkamp, 1969), 300.

${ }^{4}$ Niemieckojęzyczna wersja Wikipedii opisuje Lebensform Wittgensteina jako: „całość praktyk i sposobów działania, stosowanych w danej społeczności. Są to szablony lub wzorce, według których członkowie tejże społeczności prowadzą swoje życie lub też z których czerpią orientację dla swego życia. Całość tychże wzorców nadaje niejako najrozmaitszym wyrazom życia jedną formę".

${ }^{5}$ Ferdinand Ebner, Schriften, t. 2: Notizen, Tagebücher, Lebenserinnerungen (München: Kösel, 1963), 1069 n.

${ }^{6}$ Por. tenże, Schriften, t. 1, 349 n; Ebner, Schriften, t. 2, 1059-1105. 
muzyk Josef Matthias Hauer, którego teorię barw dźwięku Ebner rozumiał wówczas jak nikt inny i którego zainspirował do skomponowania Hölderlinliedern (Pieśni Hölderlina) 7 . To wyliczanie można by przedłużać: muzykę do opartych na ,analizie barw” tekstów poetki i malarki Hildegard Jone, niewattpliwie zainspirowanych przez Ebnera, skomponował Anton von Webern $^{8}$. Z zajmującym się również analizą barw malarzem Erichem Lechleitnerem Ebner prowadził w Innsbrucku zasadniczą dyskusję, podobnie jak i z alternatywnym pedagogiem Danielem Sailerem?.

I tak wszystko staje się jasne: mamy tu do czynienia nie z patologicznym samotnikiem, lecz z kimś, kogo zarówno dowolnie wybrane, jak i wymuszone trwanie w ,ciemnościach ducha” miało prowadzić do precyzyjnie oświetlonych „obrazów epoki”, obrazów po pierwsze tej epoki, która doprowadziła do powstania Fragmentów pneumatologicznych, w dalszej kolejności jednak obrazów każdej możliwej przeszłości - a także naszej teraźniejszości i przyszłości. Jego przyjaciel Josef Räuscher pisał o nim:

Listy i pamiętniki Ebnera świadczą w sposób jasny o tym, z jak wielką energią starał się on rozszerzyć swą wiedzę, jak zdobywał wykształcenie i dążył do prowadzenia cywilizowanego życia: czytał i pisał w sposób nieprzerwany, żywo dyskutował, prowadził może nie tyle ekstensywną, ile intensywną korespondencję, odwiedzał wystawy i słuchał koncertów.

Grał na pianinie, niewątpliwie z techniką „dyletanta”, ale jakiego dyletanta! jego tempem było adagio, z którego dokładnie trzymanego rytmu wydobywał mało wyćwiczonymi palcami melodie i harmonie powolnych zdań, jakby zostały właśnie wynalezione. Niewielu o tym wie, ci nieliczni nie zapomną jednak tego z pewnością, jak odgadł on Mozarta, tego czułego i tego strasznego ${ }^{10}$.

Przynajmniej w czasie wojny śledził on z wielką uwagą i krytycyzmem wydarzenia lokalne, krajowe i międzynarodowe. Kupował książki o sztuce z przedstawieniami rzeźb Michała Anioła, kupił Biblię ze sztychami Albrechta Dürera, zajmował się sztuką i filozofią Renesansu, a następnie sztuką i filozofią antyczną.

7 Tenże, Schriften, t. 2, 1063.

${ }^{8}$ Chodzi na przykład o Kantatę Opus 31 wiersz: „Schweigt auch die Welt, aus Farben ist sie immer".

9 Ferdinand Ebner, Mühlauer Tagebuch 23.7.-28.8.1920 (Wien: LIT, 2001).

10 Josef Räuscher - cyt. za Ficker, „Geleitwort”, 14. 
Nigdy nie uczył się greki, ale jego znajomość Platona zawstydzała zawodowych filozofów. We wszystkich obszarach wiedzy, które go dotyczyły, był na bieżąco, jakby znajdował się w centrum produkcji wiedzy wielkiego miasta. Poznawał zdumiewająco szybko wszystkie nowości ówczesnej filozofii, a szczególnie przeżywającej wówczas akurat rewolucję psychologii [...] Nie wypowiedział ani jednego osądzającego słowa o jakiejś rzeczy, zanim nie przyswoił jej sobie całkowicie. Był przeciwieństwem dyletanta ${ }^{11}$.

Ten jednak, kto określiłby go jako człowieka „wielostronnie wykształconego”, przeoczyłby całkowicie jego szczególny sposób „myślenia w odniesieniach" ${ }^{2}$, a zarazem jego na tym właśnie zbudowane rozumienie samego siebie:

Oczywiście, zaprzestałem już prób rozwinięcia się w kierunku człowieka wykształconego, a moja duchowa potrzeba orientacji jest coraz bardziej „dowolnie subiektywna”. Nie mogłem się w końcu dotąd „kształcié” inaczej niż poprzez lekturę takich dzieł, które w pewien sympatyczny dla mnie sposób wychodzily naprzeciw pytaniom rodzącym się we mnie - ale nie znajdującym we mnie samym odpowiedzi ${ }^{13}$.

Pewna skłonność do „redukcjonistycznego” myślenia, mówienia, widzenia i słyszenia daje się stwierdzić u wszystkich wymienionych postaci. A szczególnie właśnie u „fragmentysty” i ,aforystyka” Ebnera, chociaż tenże jest przy pisaniu Fragmentów boleśnie świadomy ich ,głównego braku” ${ }^{14}$ : uwięzienia w tradycyjnych schematach językowych. Przez swe nieustanne odwoływanie się do ,jedynej refleksji z perspektywy języka” Ebnerowskie myślenie zbliża się na przykład do owej purystycznej redukcji form, charakterystycznej dla opartej na „raumplanie” (planie przestrzennym) architektury Adolfa Loosa, a jeszcze bardziej zbliża się do walki Loosa przeciw ornamentowi, na którą Ebner powołuje się otwarcie jeszcze wiele lat po ukazaniu się Fragmentów:

11 Tamże.

12 Odnosząc wszelkie koncepcje i zjawiska kulturowe do siebie nawzajem i do swej „myśli podstawowej" jako do formuly, a przez to wydobywając zawsze aspekty, które się z nią (i ze sobą nawzajem) nie zgadzaja. [przyp. tłum.]

${ }^{13}$ Ferdinand Ebner, Tagebuch 1916, Fragment aus dem Jahre 1916(Wien: LIT, 2007), 26.

14 Tenże, Das Wort und die geistigen Realitäten (Wien: LIT, 2009), 15. 
Nie tylko w przedmiotach codziennego użytku uczyniliśmy poprzez ornament nasze życie nieprawdziwym - ornament przylgnął też do naszego życia duchowego i czyni je, gdy trzymamy się go zbyt mocno, w końcu nieprawdziwym. Odnosi się to także do tego, co religijne. Odnosi się to przede wszystkim do chrześcijaństwa i jego trwającego dwa tysiąclecia niezrozumienia ${ }^{15}$.

Ebner stwierdził po raz pierwszy w roku 1913 możliwą zbieżność między „,redukcjonistycznym” sposobem komponowania takich autorów, jak Anton von Webern i Josef Matthias Hauer a swoim własnym sposobem myślenia:

Istnieje więc w muzyce więcej ludzi o krótkim oddechu [wyrażenie to należy tu interpretować pozytywnie w sensie maksymalnej oszczędności środków muzycznych W.M.] (Hauer jest nieprzypadkowo przyjacielem człowieka o krótkim oddechu) [tu Ebner ma na myśli siebie, wspominając ironicznie zarówno o swych problemach z płucami, jak i oszczędność swego myślenia W.M.], którzy są wystarczająco śmiali, by uczynić z tej dolegliwości zasadę komponowania $^{16}$.

Już w czasie spisywania Fragmentów pneumatologicznych, a jeszcze wyraźniej w późniejszym okresie, Ebner znajduje się na szpicy rozwijającego się właśnie w Austrii ,krytycznego modernizmu”. U podstaw wszystkich ruchów purystycznych, które do niego prowadziły, leżała tendencja do usunięcia wszystkiego, co zbyteczne, poboczne, zarówno z procesu językowego, jak i artystycznego, architektonicznego czy muzycznego, a w końcu ze społecznego samorozumienia aż do granicy tego, co da się jeszcze przedstawić i powiedzieć, aby dokonać mediacji za pomoca jak najprostszych środków. Jest to w gruncie rzeczy - wobec wszelkich pokus monumentalizmu, które były wtedy, a są i dzisiaj, na czasie - próba głoszenia pokory.

Wszystko to, co w pismach Ebnera, przy rozszerzających się horyzontach, ukazuje się jako ,wykształcenie”, przedstawia się zawsze w ,złamaniach". Te zaś rozgałęziają się, w jakiejkolwiek dziedzinie prowadzi on swe rozważania stawiają nam przed oczami ową „formę życia” ówczesnej epoki jako konglomerat przeciwieństw i sprzeczności. Ferdinand Ebner był mistrzem w precyzyjnym rozpracowywaniu skonfliktowanych aspektów.

\footnotetext{
15 Tenże, Schriften, t. 3: Briefe (München: Kösel, 1963), 715.

16 Tamże, 23.
} 
Nawet w interpretacji myśli być może najważniejszego dostarczyciela duchowych impulsów nie zmieniał tego podejścia. „Istnieje jeden diagnostyk choroby naszych czasów - jest to Karl Kraus. Istnieje jednak także lekarz tej choroby - jest to Sören Kierkegaard" "17. Ebner zwrócił po raz pierwszy uwagę na „namiętną żarliwość myśli i wiary Sörena Kierkegaarda” dzięki tłumaczeniom autorstwa Theodora Haeckera w czasopiśmie Der Brenner, a także za sprawą ,pięknego, wypełnionego życiem tekstu” tegoż samego Haeckera pod tytułem Sören Kierkegaard i filozofia wewnętrzności ${ }^{18}$. Czytał też tłumaczenie religijnych mów Kierkegaarda Pfahl im Fleisch (Oścień w ciele) ${ }^{19}$ i Vom Tode $(O \text { śmierci })^{20}$, podobnie jak napisane w 1846 roku dzieło społeczno-krytyczne Krytyka współczesności $i^{21}$, którego fascynujący aspekt polegał dla niego na tym, że naszkicowany przez Kierkegaarda z niewiarygodna precyzją obraz współczesnego mieszczańskiego społeczeństwa, w swej myślowej wstrzemięźliwości i konsekwencji stał się naprawdę zrozumiały dopiero w wywołanym przez wojnę okresie jego upadku. W ten sposób, a także wraz z lekturą dalszych ważnych pism - w marcu 1916 czytał Pojęcie lęku, w maju Bojaźń i drżenie, na które zwrócił uwagę już jesienią 1914 roku wytworzył się w nim obraz tego filozofa jako ,jednego z najpotężniejszych myślicieli wszystkich czasów". Taki obraz przedstawia Ebner w czwartym Fragmencie. Kierkegaard staje się „,́́wiadkiem koronnym” jego własnego „myślenia z perspektywy języka”, „myśli podstawowej” Fragmentów:

Fakt, że Kierkegaard był świadom idealizmu, właściwego wszelkiemu obiektywnemu myśleniu, a przy tym świadom także rzeczywistości życia duchowego, konkretnego Ja, sprawił, że możliwe stało się to - do czego nie był zdolny żaden filozof na świecie od Platona do Kanta i Fichtego - [a mianowicie] uczynienie [z] czytelnika bezpośrednio „konkretnego” Ty, to znaczy, doprowadzenia konkretnego Ja w nim do refleksji nad sobą ${ }^{22}$.

17 Ebner, Schriften, t. 2, 410.

18 Theodor Haecker, Sören Kierkegaard und die Philosophie der Innerlichkeit (München: J.F. Schreiber, 1913).

${ }^{19}$ Ebner czytał je w tłumaczeniu niemieckim, które ukazało się w zeszytach Der Brenner: 16 (1914): 691-712; 17/18 (1914), 797-814.

${ }^{20}$ Wydane w czasopiśmie Der Brenner - Jahrbuch 1915 [ukazało się w lutym 1915], $15-55$.

${ }^{21}$ Wydane w czasopiśmie Der Brenner 19 (1914): 815 n; 20 (1914): 869-908.

${ }^{22}$ Ferdinand Ebner, Stowo i realności duchowe. Fragmenty pneumatologiczne (Warszawa: IFIS PAN, 2006), 35. 
Z drugiej strony Ebner mówi później, że Kierkegaard - podobnie jak Pascal - „myślał w cieniu Krzyża - nie oglądając nigdy światła bezpośrednio"23, i opisuje „głęboką zamkniętość jego umysłu, która sprowadza ten wybitny umysł na pełne zwątpienia i błędne drogi dialektyki [...] Jego etyka jest niczym innym, jak etyką idealizmu i samotności Ja"24. Dialektyka egzystencjalna Kierkegaarda otworzyła więc według Ebnera drogę do Ty, ale, będąc właśnie tylko dialektyka, która bez jakiegokolwiek pośrednictwa domaga się „skoku w niepewność”, jedocześnie ją zamknęła. Ebner postawił zaś od początku swego „myślenia z perspektywy języka” właśnie na pośrednictwo. W ten sposób stał się jednym z najgłębszych (najbardziej gruntownych) krytyków Kierkegaarda.

To, że „wszelkie poznanie jest zmysłowe”25, zaś słowo jest ,jednością duchowości i zmysłowości”’26 - tę sprzeczną z Kierkegaardem myśl znalazł Ebner u Johanna Georga Hamanna, którego pismami zajmował się od czerwca 1914 roku i potem szczególnie intensywnie od kwietnia 1915 roku. Ta jedność - w przeciwieństwie do kantowskiego ścisłego oddzielenia między ideą i zmysłowością - stała się dla Ebnera (tym poszukiwanym) elementem pośredniczącym: „miłość” stała się dlań „,subiektywnym”, podczas gdy słowo „obiektywnym” nośnikiem między Ja a Ty, którego brakowało mu u Kierkegaarda. Od tego odkrycia przemyślenia z ,perspektywy językowej" Ebnera rozwijają się w dwóch kierunkach: z pomocą prawie codziennej lektury Biblii starał się on zgłębiać coraz bardziej pierwotny sens słowa w Ewangelii, ale jednocześnie - nie degradując jednak przy tym języka do narzędzia - obserwował nieprzerwanie ślady ,zmysłowego" przekazu języka w „tradycji i użyciu” (jak nazywał to Hamann). Prowadził studia etymologiczne nad językami indoeuropejskimi, w których główną rolę odgrywały sanskryt i greka, oraz nad ich odniesieniami do języka niemieckiego. Stanowią one lingwistyczny fundament Ebnerowskiego myślenia. $\mathrm{Z}$ etymologii oraz ze struktury fonetycznej określonych ,słów pierwotnych” (Urworte), do których zaliczał zaimki osobowe, czasownik „być” i słowa takie jak ,człowiek”, „mąż”, ,żona” i „Bóg”, wyciagał swoje filozoficzne albo też dokładniej „pneumatologiczne” wnioski. W ten sposób włączył się częściowo, chociaż na sposób krytyczny, w myślenie etymologiczne i "literowo-mistyczne” w Niemczech: obok Hamanna jego punktami odniesienia byli Wilhelm von

\footnotetext{
${ }^{23}$ Tenże, Schriften, t. 1, 650.

${ }^{24}$ Tamże, 782.

${ }^{25}$ Ebner, Schriften, t. 3, 211 n.

26 Tenże, Schriften, t. 1, 862.
} 
Humboldt i Jacob Grimm. Jego głównym negatywnym punktem odniesienia był „obcy wszelkiej duchowości w słowie i ślepy na nią krytyk języka” Fritz Mauthner, którego dziełem Beiträgen zu einer Kritik der Sprache, wydanym w latach 1901-1902, intensywnie się zajmował i które wielokrotnie poddawał bezlitosnej krytyce.

Określenie „skonfliktowane aspekty” możemy odnieść się także do ewoluującego stosunku Ebnera do Karla Kraussa. „Mówienie i myślenie są czymś jednym" - ogłaszał tenże już w roku 1903 w swoim czasopiśmie Fackel $^{27}$. „Dla Karla Kraussa język był matką, nie zaś służącą myśli, ale ojcem było wątpienie językowe. Myślenie językowe wychodzące od językowej wiary w "początek», kontrolowane przez wątpienie językowe było warunkiem także satyrycznego i krytycznego demolowania pseudowartości literackich" 28 . Przewrotnie nadużywana prasa jest dla Krausowskiej satyry źródłem wszelkich nieszczęść na świecie, jest przeciwieństwem Ewangelii, przeciwieństwem Słowa Bożego, które było na początku. Także i temu impulsowi zawdzięcza Ebner swoją własną koncepcję języka, tym bardziej że Kraus koncentrował swą związaną przede wszystkim z wojną apokaliptyczną wizję świata coraz bardziej na apokalipsie języka. „Kraus umie jak nikt inny brać upadającą ludzkość za słowo - zacytował ją i tu musi się ona poczuć osądzona; nie przez Krausa, lecz przez jej własne słowo, które tenże pokazuje w jego prawdziwym sensie"29.

Ebner podzielał to apokaliptyczne spojrzenie na język, co sam Kraus, jak wyraził się przed swą śmiercią w 1936 roku, jak najbardziej doceniał ${ }^{30}$. Obaj mieliby dzisiaj wystarczająco dużo do roboty, chcąc pokazać spotykającą ludzkość apokalipsę medialną i jej strukturalną korupcjogenność nie tylko w mediach drukowanych, ale także w elektronicznych, w internecie

${ }^{27}$ Karl Kraus pisze w swoim czasopiśmie Die Fackel 136 (1903): 23: „Mówienie i myślenie są czymś jednym, a gryzipiórki mówią w sposób tak skorumpowany jak myślą, zaś piszą - nauczyli się, że tak ma być - tak jak mówią".

${ }^{28}$ Kurt Krolop, Sprachsatire als Zeitsatire bei Karl Kraus. Neun Studien (Berlin: Akademie-Verlag 1987), 5.

${ }^{29}$ Ebner, Schriften, t. 1, 665.

30 To jedyne zachowane odniesienie się Karla Krausa do Ebnera znajduje się w jego liście do Augusta Zechmeistera z 25.05.1936 - tu cyt. za. Gerald Stieg, Der Brenner und die Fackel. Ein Beitrag zur Wirkungsgeschichte von Karl Kraus (Salzburg: Otto Müller 1976), 206 n; por. tamże, 203-234. Bardziej obszernie zostaje to przedstawione w tejże książce Geralda Stiega, w rozdziałach: „Dokumentation“, „Ebners psychologisches Verhältnis zu Karl Kraus“, „Ebner und der Erste Weltkrieg“, „Ebner und Weininger“, „Ebners Sprachphilosophie in ihrem Verhältnis zu Kraus“. 
i w całej powodzi słów i obrazów. Jednak z tej właśnie bliskości wyrasta Ebner jednocześnie na być może najgłębszego krytyka Krausa: „A Karl Kraus? Jego pisma nie mogą działać terapeutycznie. Co nie umniejsza w żadnym razie ich wielkiej wartości, ich wybitnego znaczenia dla naszych czasów. Karl Kraus jest ostatecznie tylko błyskotliwym diagnostykiem choroby tych czasów i nie chce być niczym więcej" ${ }^{31}$.

Według Ebnera, Kraus pozostaje „ostatecznie jednak w estetycznym stosunku do słowa"32. W tym stopniu, w jakim staje się sędzią nad wszystkim, trzyma się z dala od „realności duchowej”. „Kraus, podobnie jak Kierkegaard, jeden z najbardziej «publicznych» ludzi swoich czasów, z całą swą odwagą i parciem, by eksponować się w najjaskrawszym świetle życia publicznego, należy do ludzi najbardziej samotnych - co można o nim powiedzieć oczywiście tylko jako autorze" ${ }^{33}$.

Ostrość i wielostronność Ebnerowskiej analizy współczesności, chociaż nie jest satyra, nie pozostaje w tyle za analizami czasopisma Fackel; a nawet sięga o jeden rozstrzygający krok głębiej, jeśli rozważymy zasięg jego myślenia językowego, które nie pozostaje tylko przy „klasycznych” przykładach - jak myślenie Krausa - lecz czerpie z pisemnego dziedzictwa Ewangelii. Jest ona głębsza także od analiz Adolfa Loosa:

Pod pewnym względem wydaje się, że Loos patrzył za krótko i za wąsko. (Być może moja opinia wyda się zarozumiała). Ten „,człowiek”, którego widzi on we wszystkich swych myślach jako wzorzec, ten „dobry Amerykanin”, nie jawi mi się jako jednoznaczny. Jest on przecież w swej istocie zarabiaczem pieniędzy (do egzystencji którego potrzeby duchowe wydają się doklejone jak zwykły ornament) $\mathrm{i}$ jego drugą stroną jest bycie przestępcą w największym stylu ${ }^{34}$.

Już w momencie ukazania się Fragmentów odnosił Ebner swoje zastrzeżenie $\mathrm{w}$ tej sprawie, zastrzeżenie odsłaniające także dzisiejszą uniwersalną siłę uwodzenia mediów operujących słowem i obrazem, do swej „myśli podstawowej” o „samotności Ja”:

Najokropniejsi są ludzie, których wewnętrzne nastawienie do życia i jego rzeczywistości opiera się na strasznym, de facto prowadzącym do psychozy, sza-

\footnotetext{
31 Ebner, Tagebuch 1916, 118.

32 Tenże, Schriften, t. 1, 663.

33 Tamże, 665.

${ }^{34}$ Ebner, Schriften, t. 3, 957.
} 
leństwie myśli, że za pomocą pieniędzy można w życiu wszystko osiagnąć. Tacy ludzie są po ludzku niemożliwi, gdy nie zdobędą swych pieniędzy, a stają się tacy jeszcze bardziej, gdy je zdobędą ${ }^{35}$.

Ebner starał się wyemancypować nie tylko spod wpływu Karla Krausa i Adolfa Loosa, lecz także Zygmunta Freuda. Najpierw, szczególnie około roku 1916, zajmował się intensywnie Objaśnianiem marzeń sennych (niem. Traumdeutung wydane w 1900 roku) i przeprowadzał analizy snów własnych i innych ludzi, na przykład swego przyjaciela Josefa Matthiasa Hauera, trzymając się ściśle metody Freuda, czasami także Alfreda Adlera: „Tkwi we mnie ciagle jeszcze coś z «psychologa», z człowieka, który nie może słuchać opowiadania o snach, nie próbując ich tłumaczyć"36.

Spór z Freudem i z Otto Weiningerem wprowadził go w głębię problematyki seksualności - na pewno głębiej niż działo się to przeważnie w ,rewolucji seksualnej” lat 60 . XX wieku - i w problematykę antyfeminizmu (a wraz z nią także antysemityzmu) oraz feminizmu. Nie zatrzymał się jednak w tym punkcie. Ebner przekroczył wkrótce Freudowski rozwinięty dla indywidualnej psychoanalizy model „funkcjonalny” i przekształcił go w swój własny kulturowo-krytyczny model „snu o duchu”, który zawiera w sobie wszystkie aspekty zachowania się w „samotności Ja”, czy chodzi przy tym o nierozumiejącą samej siebie religijność, czy też o wyczerpującą się w idealizmie filozofię, zdegenerowaną do ideologii naukę ścisłą, a nawet kulturę jako taką.

Podczas gdy dla Freuda wythumaczone marzenie senne jest „,via regia do poznania tego, co w życiu psychicznym nieświadome", dla Ebnera wytłumaczony sen o duchu jest via regia do poznania realności w życiu duchowym, które to, wyparte, powracają w tym właśnie śnie [...] Odo Marquard interpretuje Freuda następująco: „wyparte zostają w równym stopniu niesłusznie odrzucony ratunek - pseudonim Eros - i słusznie wypędzona zguba - pseudonim popęd śmierci”. Przetłumaczone na język Ebnera mogłoby to brzmieć tak: zanegowane zostaje niesłusznie odrzucone zbawienie - pseudonim $J a, T y, B o ́ g$ - i w równym stopniu niesłusznie wypędzona zguba - pseudonim zlamanie $^{37}$.

35 Tamże.

${ }^{36}$ Ebner, Tagebuch 1916, 56.

${ }^{37}$ Klaus Dethloff, Ferdinand Ebner und die Psychoanalyse oder Träume vor und nach dem Einschlafen, w: Gegen den Traum vom Geist. Ferdinand Ebner. Beiträge zum Symposion Gablitz 1981 (Salzburg: Otto Müller, 1985), 170. 
I tak wzorem dla Ebnerowskiego modelu ,snu o duchu” jest Freudowskie podejście indywidualno-psychologiczne, jako ,tylko-naukowe”, „w samotności Ja", a przez to samo uwięzione w ,śnie o duchu". To właśnie doprowadziło do zasadniczej rozprawy z psychologią i psychoterapią we Fragmencie $9^{38}$.

W ten sposób stronnicze są oczywiście nauki ścisłe, w szczególności te nawiązujące do Darwinowskiej teorii ewolucji, które kształtowały w czasie pisania Fragmentów naukowy obraz świata. Spór Ebnera z ówczesną recepcją Darwina może rozświetlić współczesny spór między „darwinowską ewolucją" a intelligent design.

W swojej książce The God Delusion, która zdobyła w ostatnich latach spory rozgłos, brytyjski biolog ewolucyjny Richard Dawkins twierdzi, że naturalny dobór i inne teorie naukowe lepiej nadają się do wyjaśniania świata żywego, a może nawet i Kosmosu, niż „hipoteza Boga" ${ }^{39}$. Ubolewa też, że wielu naukowców, nawet Albert Einstein, używają słowa „Bóg” na sposób panteistyczny i poetycki, jako metaforę dla Natury i tajemnic Wszechświa$\mathrm{ta}^{40}$. Widoczna nieprawdopodobność stwierdzalnej kompleksowości, wysokiej złożoności życia nie uprawnia jednak do postulowania jakiegoś design (projektu) lub Projektanta ${ }^{41}$.

Chociaż Ebner w swoich czasach nie mógł nic wiedzieć o porównywaniu sekwencji genów i innych badaniach biologii molekularnej, które czynią dziś ewolucjonizm tak atrakcyjnym, nie byłoby to dla niego żadną nowością. Częściowo nawet by się z tym zgodził. Gdy jednak Dawkins twierdzi, że potrzeba pocieszenia i inspiracji zostaje lepiej niż przez religię zaspokojona za pomocą środków niereligijnych, jak filozofia i nauki przyrodnicze, zaś ateizm jest „wglądem zdrowego, niezależnego umysłu” "42, Ebner stwierdziłby, że absolutyzuje on i degraduje szanującą się naukę do ideologii.

Ewolucjonizm naszych czasów, prezentujący się co prawda bardzo naukowo, lecz w końcu jednak odbiegający od swego tematu na rzecz metafizyki, upaja się myślami o wiecznym stawaniu się i przemijaniu wszystkich bytów - a przez to pokazuje, że optymizm rozwoju mimo wszystko nie jest tak doskonały. Sam „rozwój” - jak tego doświadczyliśmy - sprowadza go ad absurdum ${ }^{43}$.

\footnotetext{
38 Ebner, Das Wort, 79 n.

39 Richard Dawkins, The God Delusion (London: Bantam, 2006), $1 \mathrm{n}$.

40 Tamże, 18.

41 Tamże, 114.

42 Tamże, 3.

${ }^{43}$ Ebner, Stowo i realności, 214.
} 
O Bogu nie da się po prostu mówić w trzeciej osobie, lecz jedynie do Boga - w drugiej. Już określenie ,hipoteza Boga” pozwala poznać, jak zasadniczo fałszywy jest sąd Dawkinsa odnośnie do stosunku człowieka do Boga. „Jedno jest jasne: odnośnie do problemu mowy, niedoskonałość myśli ewolucyjnej - i dlatego też niemożliwość jej utrzymania - jest najbardziej wyraźna (przy problemie mowy, ale także problemie człowieka - bowiem oba są jednym i tym samym)"'44.

Nauki, włącznie z teologią i psychologią, które stoją w swej pracy z otwartością wobec tego problemu i starają się uczynić mu zadość, choćby na sposób „niedoskonałej pokuty”45, mogły i mogłyby nadal liczyć na uznanie Ebnera. Misjonarski zapał Dawkinsa w propagowaniu ateizmu byłby jednak dla Ebnera jedynie grą pozorów, podobnie jak atakowane przez niego w swoim czasie tezy takich autorów, jak Ernst Haeckel i Wilhelm Oswald, Hermann Klaatsch ${ }^{46}$ czy Paul Kammerer ${ }^{47}$.

Jeśli chodzi jeszcze o „skonfliktowane aspekty”: jedyne czasopismo, w którym Ebner przez całe życie publikował, Der Brenner w Innsbrucku, wraz z przynależnym doń Wydawnictwem Brenner (Brenner Verlag), w którym ukazały się po raz pierwszy w 1921 roku w całości Fragmenty pneumatologiczne, już od czasu swego powstania w roku 1910, a szczególnie bezpośrednio po I wojnie światowej, odróżniało się zasadniczo od wszelkich innych niemieckojęzycznych czasopism kulturalnych swojej epoki. Der Brenner nie realizował żadnego sformułowanego uprzednio programu kulturalnego: jego wydawca, Ludwig von Ficker, inscenizował - jak sam to formułował: „na miarę wewnętrznej gotowości” - całkowicie świadomie konfrontację między współpracownikami i między ich przeciwstawnymi punktami widzenia. Prowadziło to $\mathrm{w}$ ramach czasopisma niejednokrotnie do groźby rozłamu, a kilka razy nawet do przejściowych przerw w ukazywaniu się czasopisma ${ }^{48}$.

Od okresu przedwojennego i czasów pierwszej wojny, od razu po wznowieniu wydawania Brennera pod koniec października 1919 roku, zapewniona była wzorcowo jednoczesna obecność wątków wzajemnie się wyklu-

44 Tenże, Mühlauer, 30.

45 Tak właśnie jako „niedoskonałą pokutę” opisywał Georg Trakl przed powołaniem do armii swoją poezję.

46 Ebner, Schriften, t. 1, $791 \mathrm{n}$.

47 Tenże, Mühlauer, 28.

48 Walter Methlagl, „An der Grenze des Sagbaren. Der «Brenner-Kreis»”, w: Das größere Österreich. Geistiges und soziales Leben von 1880 bis zur Gegenwart, red. Kristian Sotriffer (Wien: Edition Tusch, 1982), 148 n. 
czających. Z jednej strony - reprezentowana przez Carla Dallago „wysoka mądrość Chin, która migocze do nas z ekstazy Lao-Tse [także: Laozi] przez dwa i pół tysiąca lat”, z drugiej - „,namiętna żarliwość myśli i wiary Sörena Kierkegaarda, która niesamowicie nieporuszona, jak płonąca bez końca burza, przewyższa zapadający się horyzont świata zachodniego". W tym wzajemnym prześwietlaniu się obu podejść miało paść według Fickera rozstrzygnięcie, „które będzie posiadać najwyższą wagę dla duchowej orientacji naszych czasów, na ile chcą one przyswoić sobie swe religijne przeznaczenie"49. W tę właśnie poszukującą rozstrzygnięcia sytuację włączają się od pierwszego powojennego zeszytu publikacje pierwszych Fragmentów z głównego dzieła Ebnera. Trudno znaleźć lepszy grunt dla gotowości do podejmowania konfliktów, jaka przebija z Fragmentów i artykułów w Der Brenner. Aby „utrafić ten ton, na którym opierać się ma to czasopismo, od samego początku tak czysto i w pełnym brzmieniu, jak to tylko możliwe" Ludwig Ficker umiejscowił pierwsze Fragmenty Ebnera celowo w napięciu między Lao-Tse i Kierkegaardem, którego myśl zostaje z czasem jeszcze zaostrzona przez zwracającego się po swojej konwersji coraz bardziej ku katolickiej ortodoksji Theodora Haeckera.

Ebner wzbudzał wśród innych współpracowników i czytelników czasopisma i jego głównego dzieła oczekiwane wzburzenie. Na przykład Carl Dallago, ze względu na którego Ficker kiedyś założył Brenner, gwałtownie odrzucił od razu całe centralne dla Fragmentów podejście z perspektywy języka i przeciwstawił mu swoje własne, zorientowane na Lao-Tse, mistyczne podejście koncentrujące się na bezsłownym zjednoczeniu Boga i człowieka: „Ja i Ty w sensie duchowym i religijnym zatracają coraz bardziej swoje granice, stapiają się ze sobą, a słowo jako część języka milknie, im bardziej stosunek do Boga w człowieku znajduje swój egzystencjalny wyraz"s1.

Gwałtowność tego odrzucenia kazała Ebnerowi przejściowo wątpić w sens dalszej współpracy z Brennerem. Na dłuższą metę wzmocniło to jego zastrzeżenia wobec wszystkiego, co sprawiało wrażenie mistycznego zjednoczenia. Jego niechęć wzbudzało to, co było we wszelkim mistycznym poznaniu „osobowo-niezobowiązujące”: „Głębia myśli mistyków jest samooszukiwaniem się"52. „Tao jest duchowo bezpośrednim przeciwieństwem Logosu, próbą ludzkiej egzystencji poza Logosem i grzechem. Coś

\footnotetext{
49 Ludwig Ficker, „,Vorwort zum Wiederbeginn”, Der Brenner 1 (1919): 2.

50 Tenże, Briefwechsel 1914-1925 (Innsbruck: Haymon, 1988), $182 \mathrm{n}$.

${ }^{51}$ Carl Dallago, ,Augustinus, Pascal und Kierkegaard”, Der Brenner 9 (1921): 641-734.

${ }^{52}$ Ebner, Stowo i realności, 173.
} 
takiego możliwe jest jedynie jako zjawisko przedchrześcijańskie albo jest ucieczką"53. W dążeniu, przemawiającym z opinii Dallago, dążeniu do rozpuszczenia Ja we wszechświecie i w początku wszystkich rzeczy, mistyk rozmywa granicę między Stwórcą a jego stworzeniem; granicę, która jest dostrzegalna i możliwa do zachowania jedynie w wierze w Słowo, które stało się ciałem ${ }^{54}$.

Wychodząc od tego samego zastrzeżenia, możemy także wyjaśnić stosunek Ebnera do Martina Bubera (który oczywiście nie należał do współpracowników Der Brenner). Długi czas spoglądano na Ebnerowskie podejście z perspektywy języka jako na pochodną dialogicznego myślenia Bubera i nie dostrzegano, że odwrotnie, to Buber, zanim w roku 1922 zakończył trzecią część swego dzieła Ja i Ty, czytał artykuły Ebnera w Der Brenner i Fragmenty w formie książkowej55. Obu łączyła myśl, że Boga można nazwać tylko „Ty” i że niemożliwe jest mówienie o Bogu w trzeciej osobie. W przeciwieństwie do Ebnera Buber rozszerzył dialogiczny stosunek także na „kosmiczny” stosunek człowieka do natury. Ebner przyznał Buberowi, że poznał on fatalne konsekwencje przemiany „zdania pierwotnego” „Ty jesteś” w „on jest”: „Nie wyciagnął stąd jednak dwóch, swoją drogą niemniej oczywistych i decydujących konsekwencji - ale to jest charakterystyczne dla nastawionego lirycznie mistyka - że trzeba też przemyśleć «samotność Ja» i śniony w niej «sen o duchu»"

Gdy chodzi o jego „podejście” do relacji Ja-Ty, Ebner wypracowywał także odnośnie do najbliższych mu intelektualnie myślicieli przede wszystkim „aspekty pozostające w konflikcie”: Ludwig Feuerbach, „ten w swoim materializmie i sensualizmie tak bardzo niezrozumiany «odkrywca Ja i Ty»" "57 (na którego dopiero po ukazaniu się Fragmentów zwrócił Ebnerowi uwagę Hans Ehrenberg) $)^{58}$, widział to odkrycie jako podstawę swej „Filozofii przyszłości”, ale nie dostrzegał, „że filozofia właśnie w tej przyszłości nie ma przyszłości”59. Z drugiej strony Buber widzi stosunek Ja do Ty „nie

${ }^{53}$ Tenże, Schriften, t. 2, 389.

${ }^{54}$ Tenże, Mühlauer, 28.

${ }_{55}$ Rivka Horwitz, „Ferdinand Ebner als Quelle von Martin Bubers Ich und Du”, w: Untersuchungen zum „Brenner”. Festschrift für Ignaz Zangerle zum 75. Geburtstag (Salzburg: Otto Müller, 1981), 283 n.

${ }^{56}$ Ebner, Schriften, t. 1, 583 n.

57 Tamże, 571.

58 Por. Ebner, Schriften, t. 3, 465 n.

59 Tu Ebner odnosi się do tytułu i treści książki Feuerbacha Filozofia Przyszłości, wydanej jako Philosophie der Zukunft (Stuttgart: Frommanns Verlag, 1922). 
inaczej jak w poetyckim przeobrażeniu, a więc nie w jego całkowicie niepoetyckiej rzeczywistości" ${ }^{60}$.

Jeszcze przed ukazaniem się w wydawnictwie Brenner całej książki wydrukowany w czasopiśmie pod tytułem Kultura i chrześcijaństwo osiemnasty Fragment odebrany został przez niektórych z najbliższych przyjaciół Fickera jako prowokacja. Na przykład malarz i profesor sztuki Erich Lechleitner poczuł się w centrum swej pracy artystycznej i wychowawczej dotknięty takimi sformułowaniami jak „chrześcijaństwo, które przezwycięża śmierć”, które „stoi ponad wszelką formą i kulturą”, nie daje się zintegrować w żadnej kulturze i „nie może nic wnieść do kultury danego społeczeństwa”. Ebner pisał: „Myśl, że wewnątrz chrześcijaństwa nie ma ostatecznie miejsca na artystyczne nastawienie egzystencjalne, nie znajduje w nim akceptacji, w człowieku, w którym istnieje uczciwe artystyczne chcenie i poszukiwanie jakiegoś sprawiającego chrześcijańskie wrażenie poddania się całej ludzkości”61.

To zgadzało się także z podstawowymi zastrzeżeniami, jakie Ebner mimo zrozumienia jej szczegółów i osobistej bliskości z jej Autorem - miał wobec twórczości kompozytorskiej, a jeszcze bardziej wobec wiążącego się z nią „kosmicznego światopoglądu” Josefa Matthiasa Hauera. Jego głęboka analiza teorii barw dźwięku Hauera, na przykładzie jego Fantazji Apokaliptycznej, prowadzi ostatecznie do tego samego „modelowego” zastrzeżenia, które skierowane jest równocześnie przeciw malarzowi Lechleitnerowi i muzykowi Hauerowi:

Malarz może na przykład w przeżywaniu pewnego określonego koloru mieć swoje niedefiniowalne przeżycie, które nie da się zinterpretować czysto estetycznie, bowiem zostało podkreślone w sposób formalnie mistyczny; coś podobnego dzieje się prawdopodobnie z człowiekiem muzyki w jego wewnętrznym przeżyciu interwałów. Także określaniu kierunków poruszania się w przestrzeni (horyzontalnie, wertykalnie, diagonalnie, w prawo, w lewo, w górę, w dół) oraz geometrycznemu określaniu obszarów (np. koło lub trójkąt) mogą towarzyszyć pewne „mistycznie” konkretne rezultaty ${ }^{62}$.

${ }^{60}$ Ebner, Schriften, t. 1, 584.

61 Tenże, Mühlauer, $37 \mathrm{n}$.

${ }^{62}$ Ebner wyraża się w ten sposób w swym artykule: „Josef Hauers Apokalyptische Phantasie", w: Ebner, Schriften, t. I, 378 n. Sformułowania te znajdujemy także w prawie niezmienionym brzmieniu w zastosowaniu do pewnego obrazu Ericha Lechleitnera. Por. Walter Methlagl, Erich Lechleitner 1879-1959 (Innsbruck: Haymon, 2003), 89. 
Takie psychologicznie określane „mistyczne” zachowanie sprowadza jednak raz po raz wszelkiego rodzaju artystów do mieszania tego, co estetyczne, z tym, co religijne: „Przede wszystkim trzeba jednak [...] zdecydowanie przestrzec przed pojmowaniem Fantazji Apokaliptycznej [chodzi o kompozycję J. M. Hauera o tym tytule - przyp. thum.] jako w swej ostatecznej podstawie dzieła o sensie «religijnym». Co ma sztuka wspólnego z religią?" 63 .

Jeśli chodzi o przynajmniej możliwość sztuki rozumianej po chrześcijańsku, to oczywiście spory Ebnera z Erichem Lechleitnerem, a potem z Josefem Humplikiem i Hildegard Jone, przyczyniły się do późniejszego znaczącego złagodzenia, jeśli nie porzucenia tego „pesymizmu kulturowego”, który we Fragmentach jeszcze całkowicie dominuje ${ }^{64}$. Ebner rozróżnia przy tym ściśle między sztuką obrazu i sztuką słowa:

Pytanie, jak artysta, jak poeta może trwać w duchu chrześcijaństwa egzystencjalnie, bez wewnętrznej sprzeczności i oszukiwania siebie [...] musi zostać rozwiązane dla każdego z osobna, dla artysty i dla poety [...] Poeta ma więc do czynienia ze słowami [...] Słowo jest, i to u samych swych podstaw, czymś całkowicie innym niż zwykły materiał estetyczny, jak to jest z materiałem artysty plastyka, czy jest to drewno, kamień, barwa czy brzmienie. I tak być może w duchu chrześcijaństwa egzystencja artystyczna nie jest czymś całkiem niemożliwym $[\ldots]$ jednak całkowicie niemożliwa i to ze swej istoty niemożliwa jest egzystencja artystyczna poety ${ }^{65}$.

Właśnie to rozróżniające kryterium zastosował Ebner do innego współpracownika Brennera i do dwóch jego lirycznych prekursorów - do Charlesa Baudelaire'a z jego buntowniczym je ne veux pas! i do Georga Trakla, któremu co prawda przyznaje: „Istnieją wiersze, które na łożu śmierci wewnętrznie rozkładającej się kultury rozkwitają ze wspaniałą pięknością. Tego rodzaju są właściwie już wiersze Hölderlina, ale jeszcze bardziej Georga Trakla"66.

${ }^{63}$ Ebner, Schriften, t. 1, 379; por. Dieter Bogner, „Itten in Wien”, w: Johannes Itten und die Moderne, red. Christa Lichtenstern, Christoph Wagner (Ostfildern: Hatje Cantz Verlag 2003); Jörgen Jensen, „Ferdinand Ebner und Josef Matthias Hauer”, w: Untersuchungen zum „Brenner”. Festschrift für Ignaz Zangerle zum 75. Gebrutstag, red. Walter Methlagl, Eberhard Sauermann (Salzburg: Otto Müller, 1981), 242-272.

${ }^{64}$ Methlagl, Erich Lechleitner, 91.

${ }^{65}$ Cyt. za: tenże, Erich Lechleitner, 90 n.

${ }^{66}$ Ferdinand Ebner, Wort und Liebe (Hamburg u.a.: LIT, 2015), 44. 
Ale także Baudelaire i Trakl tworzyli według Ebnera „w cieniu Krzyża" ${ }^{67}$ : „Wiersze Georga Trakla: Słowo ma samowolę poetycko spełnionej samotności Ja"68. Przy wszystkich tych sporach znajdujemy się ciagle w sferze konfliktu między słowem a obrazem, który w naszych czasach grozi rozszerzeniem się w nowych konstelacjach do ogólnoświatowej, niebezpiecznej konfrontacji.

Tak jak u Wittgensteina i innych, także i u Ebnera dochodzi przejściowo do głosu - co wyjaśnia częściowo częste powoływanie się na Blaise Pascala - pewien moment ,jansenistyczny” a nawet „kryptoprotestancki” i rodzi właśnie w czasie spisywania Fragmentów tenże antagonizm (co przysporzyło Ebnerowi problemów z kościelną cenzurą i to jeszcze nawet po II wojnie światowej).

Ebner nie był w Austrii jedynym katolikiem, w którym - pod naciskiem narzuconej przez Kościół teologii obrazu, opartej na obrazie liturgii i duszpasterstwa - zrodziło się silne pragnienie Objawienia w Słowie zamiast barokowej epifanii obrazu. Jego chrześcijaństwo, jakie ukazuje się we Fragmentach, nie było jakimś systemem zamkniętym. Nie było ono identyczne $\mathrm{z}$ religią biedermaierowska, która odbierana jest w sensie czegoś, co można posiadać, jako teologicznie ustalony światopogląd i kolorowy folklor. Wychodzący z Fragmentów ,impuls antyinstytucjonalny, który stawia osobistą, żywą relację z Bogiem i z drugim człowiekiem ponad sztywną doktrynę i zwyczajowe masowe praktyki" ${ }^{69}$, nie znajdował się już w cieniu Kontrreformacji i Metternichowskiego powiązania tronu z ołtarzem, które aż do I wojny światowej i nawet po załamaniu się monarchii pociagało za sobą w Austrii fatalne konsekwencje.

Ebner poświadczał zawsze, że Kościół katolicki wiarygodnie przekazał Słowo, „które było na początku i które stało się Ciałem”. To ,jądro” zawsze cenił, za zgorszenie uznawał przez długi czas „łupinę”, przede wszystkim skłonność Kościoła do reprezentacji ${ }^{70}$.

${ }^{67}$ Tenże, Schriften, t. 1, 650.

${ }_{68}$ Tenże, Schriften, t. 2, 396.

69 Stieg, Der Brenner, 223.

${ }^{70}$ W swoim artykule „Ärgernis der Repräsentation” (,Zgorszenie reprezentacji”) (Ebner, Schriften, t. I, 506-522) krytykuje Ebner skłonność Kościoła do zewnętrznego, obrazowego, „teatralnego” interpretowania chrześcijaństwa. Ebner pisze tam na przykład: „W felietonie pewnego chrześcijańskiego dziennika czytamy, co działo się we wcześniejszych czasach w czasie Wielkiego Tygodnia. «W Klosterneuburg odbywała się w tym czasie w każdy Wielki Piątek procesja, która szła od kościoła św. Marcina do kolegiaty i przedstawiała żywo dramatyczną Drogę Krzyżową, w której nie brakowało nawet poszczególnych Prawzorów Chrystusa ze 
Nie można jednak przeoczyć, że w ostatnich latach przed swą wczesną śmiercią, Ebner dopuszcza pewną możliwość widzenia i przedstawiania świata na sposób artystyczny i muzykalny, a nawet poetycki, widzenia oczywiście zainspirowanego pierwotnie przez słowo, a więc swoiste pojednanie między słowem a obrazem. $Z$ taką inspiracją praca artystyczna i jej rezultaty mogły być postrzegane jako antycypowane, zmysłowo postrzegalne metafory działającego w świecie zbawienia. Wszystko wskazuje na to, że przed śmiercią dokonało się także pojednanie Ebnera z Kościołem katolickim. Dlatego też można powiedzieć: W Austrii nie było w ostatnim stuleciu i nie ma do dzisiaj ani ze strony protestanckiej, ani ze strony katolickiej tak mocno po chrześcijańsku ugruntowanej krytyki naszych czasów i społeczeństwa jak krytyka Ferdinanda Ebnera. We wszystkich wspomnianych tu aspektach, na ile dadzą się one przenieść na naszą współczesność, a także w wielu apektach pominiętych, Ebnerowskie nieprzerwane wypracowywanie ,skonfliktowanych aspektów” potrzebuje pilnie kontynuacji, aby mogły w przyszłości mieć miejsce wiarygodne pojednania. Dzisiejsza sytuacja jest jeszcze bardziej paląca niż 7 września roku 1921, gdy Ebner otrzymał pierwszy wydrukowany egzemplarz swoich Fragmentów pneumatologicznych.

ttum. Krzysztof Skorulski

\section{Conflicting Aspects. Ferdinand Ebner's „Thinking in References” (Summary)}

There are substantial difficulties in assessing the place of Ferdinand Ebner in the intellectual, cultural, and religious life of his epoch. Some authors see in him merely - though unfairly - a hermit cut off from the world, immersed in ,the darkness of the spirit", obstinately repeating the same statements. Another unfair interpretation

Starego Testamentu, zaś do scenicznego dopełnienia wprowadzano wszystko, co mogło w jakiś sposób wzbudzać iluzję, na przykład jeźdźców Setnika Longinusa, poszczególne odgrywające swą rolę osoby i masy ludu, niewiasty jerozolimskie, pokutników idących za Chrystusem i ciągnących krzyż, kończyli ją zaś uroczyście proboszcz ze swoimi asystentami, kościelnymi, muzykantami, radą miejską Klosterneuburga, mieszczanie i «pobożne kobiety»". No cóż, jeśli wiara w Chrystusa i jego słowo, które działa w sercu człowieka, żyjąc i stwarzając życie, ma tam być obecne jako „dzieło Boże” (J 6, 29), gdy pokorne uniżenie się człowieka przed Krzyżem ... miałaby znaleźć swój wyraz w tego rodzaju teatrze ulicznym, w którym jest tyle maskarady i widowiska, to nie da się na to patrzeć bez wątpliwości...” (Ebner, Schriften, t. 1, 106). 
would be to define him as a typical, educated man of science. What was specific for Ebner was his ,thinking in references“. Setting a basic idea in the center of his thought, he went on to study professionally the most various and informative topics. Then, he referred the results to the basic idea, as well as he juxtaposed them with each other. The purpose was to find ,the conflicting aspects“, mutual contradictions between the analyzed elements. Hence, Ebner can be called a leading representative of ,critical modernism“ that was developing in Austria at that time. All the purist movements which contributed to that current focused on removing everything that was needless and secondary from the linguistic, artistic, architectonic, and musical processes. Thanks to that also social self-understanding was to become simplified. Any content to be presented or spoken out should be mediated by the simplest means. In this sense Ebner is both part of a ,living form“ of his epoch, and a creator of the philosophy, culture, and religion proper to that period.

Key words: Ferdinand Ebner; modernism; Wien; psychology; Sigismund Freud; music; Josef M. Hauer; culture; Karl Kraus; art; Hildegard Jone; Erich Lechleitner; architecture; Adolf Loos; the philosophy of dialogue; Richard Dawkins; conflicting aspects.

\section{Konflikt aspektów. Ferdinanda Ebnera „myślenie w odniesieniach” (Streszczenie)}

Istnieją spore trudności w oszacowaniu miejsca Ferdinanda Ebnera w ramach życia intelektualnego, kulturalnego i religijnego jego epoki. Niektórzy widzą w nim wręcz - niesłusznie - odgrodzonego od świata samotnika zanurzonego w ,ciemnościach ducha”, z uporem maniaka powtarzającego ciągle to samo. Równie niesłuszne jest jednak ujmowanie go w kategoriach typowego wykształconego „,człowieka nauki”. Specyfikę Ebnera można próbować uchwycić od strony jego „myślenia w odniesieniach", jako myśliciela stawiającego w centrum swą „myśl podstawową" i zgłębiającego w sposób niedopuszczający dyletanctwa najrozmaitsze, lecz wnoszące coś nowego do dziedziny, by odnieść je do swego centrum oraz do siebie nawzajem i znaleźć ,skonfliktowane aspekty” - wzajemne sprzeczności wewnątrz tych zjawisk oraz między nimi a jego myślą podstawową. I tak dostrzegamy, że Ebner znajduje się na szpicy rozwijającego się właśnie w Austrii „krytycznego modernizmu". U podstaw wszystkich ruchów purystycznych, które do niego prowadziły, leżała tendencja do usunięcia wszystkiego, co zbyteczne, poboczne, zarówno z procesu językowego, jak i artystycznego, architektonicznego czy muzycznego, a w końcu ze społecznego samorozumienia, docierając aż do granicy tego, co da się 
jeszcze przedstawić i powiedzieć, aby dokonać mediacji za pomocą jak najprostszych środków. I Ebner w tym sensie zarówno znajduje się w „formie życia” (pojęcie Wittgensteina) swojej epoki, jak i ją kształtuje, szczególnie gdy chodzi o filozofię, kulturę, jak i religię.

Słowa kluczowe: Ferdinand Ebner; modernizm; Wiedeń; psychologia; Zygmunt Freud; muzyka; Josef M. Hauer; kultura; Karl Kraus; sztuka; Hildegard Jone; Erich Lechleitner; architektura; Adolf Loos; filozofia dialogu; Richard Dawkins; conflicting aspects.

\section{Bibliografia}

Bogner, Dieter. „Itten in Wien”. W: Johannes Itten und die Moderne, red. Christa Lichtenstern, Christoph Wagner. Ostfildern: Hatje Cantz Verlag, 2003.

Dallago, Carl. „Augustinus, Pascal und Kierkegaard”. Der Brenner 9 (1921): 641-734 .

Dawkins, Richard. The God Delusion. London: Bantam, 2006.

Dethloff, Klaus. „Ferdinand Ebner und die Psychoanalyse oder Träume vor und nach dem Einschlafen". W: Gegen den Traum vom Geist. Ferdinand Ebner. Beiträge zum Symposion Gablitz 1981, red. Walter Methlagl, 162-173. Salzburg: Otto Müller, 1985.

Ebner, Ferdinand. Das Wort und die geistigen Realitäten, red. Richard Hörmann. Wien: LIT, 2009.

Ebner, Ferdinand. Mühlauer Tagebuch 23.7.-28.8.1920, red. Richard Hörmann, Monika Seekirchner. Wien: LIT, 2001.

Ebner, Ferdinand. Schriften, t. 1: Fragmente Aufsätze Aphorismen. Zu einer Pneumatologie des Wortes, red. Franz Seyr. München: Kösel, 1963.

Ebner, Ferdinand. Schriften, t. 2: Notizen, Tagebücher, Lebenserinnerungen, red. Franz Seyr. München: Kösel, 1963.

Ebner, Ferdinand. Schriften, t. 3: Briefe, red. Franz Seyr. München: Kösel, 1963.

Ebner, Ferdinand. Stowo i realności duchowe. Fragmenty pneumatologiczne, thum. Krzysztof Skorulski. Warszawa: IFIS PAN, 2006.

Ebner, Ferdinand. Tagebuch 1916. Fragment aus dem Jahre 1916, red. Markus Flatscher, Richard Hörmann. Wien: LIT, 2007.

Ebner, Ferdinand. Wort und Liebe, red. Richard Hörmann, Krzysztof Skorulski. Hamburg u.a.: LIT, 2015.

Feuerbach, Ludwig. Philosophie der Zukunft. Stuttgart: Frommanns Verlag, 1922. 
Ficker, Ludwig. „Geleitwort”. W: Ferdinand Ebner, Schriften, T. 1: Fragmente Aufsätze Aphorismen. Zu einer Pneumatologie des Wortes, red. Franz Seyr, 7-18. München: Kösel, 1963.

Ficker, Ludwig. „Vorwort zum Wiederbeginn”. Der Brenner 1 (1919): 1-4.

Ficker, Ludwig. Briefwechsel 1914-1925. Innsbruck: Haymon, 1988.

Haecker, Theodor. Sören Kierkegaard und die Philosophie der Innerlichkeit. München: J.F. Schreiber, 1913.

Horwitz, Rivka. „Ferdinand Ebner als Quelle von Martin Bubers Ich und Du”. W: Untersuchungen zum „Brenner“. Festschrift für Ignaz Zangerle zum 75. Geburtstag, red. Walter Methlagl, Eberhard Sauermann, 283-293. Salzburg: Otto Müller, 1981.

Jensen, Jörgen. „Ferdinand Ebner und Josef Matthias Hauer”. W: Untersuchungen Zum ,Brenner”. Festschrift für Ignaz Zangerle zum 75. Gebrutstag, red. Walter Methlagl, Eberhard Sauermann, 242-272. Salzburg: Otto Müller, 1981.

Krolop, Kurt. Sprachsatire als Zeitsatire bei Karl Kraus. Neun Studien. Berlin: Akademie-Verlag, 1987.

Methlagl, Walter. „An der Grenze des Sagbaren. Der «Brenner-Kreis»”. W: Das größere Österreich. Geistiges und soziales Leben von 1880 bis zur Gegenwart, red. Kristian Sotriffer, 148-152. Wien: Edition Tusch, 1982.

Methlagl, Walter. „Woge und Kristall. Georg Trakl - Hildegard Jone - Anton von Webern". Das Fenster. Tiroler Kulturzeitschrift 42 (1987): 4130-4134.

Methlagl, Walter. Erich Lechleitner 1879-1959. Innsbruck: Haymon, 2003.

Stieg, Gerald. Der Brenner und die Fackel. Ein Beitrag zur Wirkungsgeschichte von Karl Kraus. Salzburg: Otto Müller 1976.

Wittgenstein, Ludwig. Schriften, t. 1. Frankfurt a. M.: Suhrkamp, 1969.

Wucherer-Huldenfeld, Augustinus, Carl. Personales Sein und Wort. Einführung in den Grundgedanken Ferdinand Ebners. Wien: Böhlau, 1985. 
